\title{
Differential Colonization of Plant Parts by the Rumen Microbiota is likely to be due to Different Forage Chemistries
}

\author{
Sharon A Huws ${ }^{1 *}$, Olga L Mayorga ${ }^{1,2}$, Michael K Theodorou ${ }^{1}$, Eun $\mathrm{J} \mathrm{Kim}^{3}$, Alan H Cookson ${ }^{1}$, Charles $\mathrm{J} \mathrm{Newbold}^{1}$ and Alison H Kingston- \\ Smith ${ }^{1}$ \\ ${ }^{1}$ Institute of Biological, Environmental and Rural Sciences (IBERS), Aberystwyth University, Penglais campus, Aberystwyth, UK \\ ${ }^{2}$ Centro de Investigación Tibaitatá, CORPOICA, Kilómetro 14 Via Mosquera (Cundinamarca), Colombia \\ ${ }^{3}$ Department of Animal Science, Kyungpook National University, Sangju, Korea
}

\begin{abstract}
In this experiment we investigated the hypothesis that heterogeneity of plant structures presents disparity in niches available for colonisation by the rumen microbiota resulting in differential colonisation. Fresh perennial ryegrass (PRG) stem and leaves were incubated in the presence of rumen bacteria under rumen-like conditions with incubations harvested at many time intervals up to $24 \mathrm{~h}$. In vitro dry matter degradability (IVDMD) of stem material was lower than that of leaves at all harvesting times. Denaturing Gradient Gel Electrophoresis (DGGE) derived dendrograms, canonical analysis of principal coordinates (CAP) and PERMANOVA demonstrated that diversity of bacteria attached to PRG stem and leaf material was different at all harvesting times although QPCR data showed similar quantities of bacterial $16 \mathrm{~S}$ rDNA on stem and leaf material at all harvesting times. Conversely, bacterial diversity on abaxial and adaxial leaf surfaces was similar, but 16S rDNA quantity differed with more 16S rDNA on the adaxial surface at all harvesting times. Image analysis of low temperature scanning electron microscopy (LTSEM) pictures confirmed that biofilm coverage on the adaxial surface was greater than the abaxial surface. We demonstrate that differing plant parts can affect attached bacterial diversity and/or 16S rDNA quantity present. This result is consistent with concepts of niche specialisation by the rumen microbiota. This observation is particularly relevant to understanding rumen plant-microbe interactions which is necessary for development of novel strategies for improving ruminant nutrient use efficiency.
\end{abstract}

Keywords: Colonisation; Rumen; Bacteria; Stem; Leaf; Abaxial; Adaxial; DGGE; QPCR

\section{Introduction}

With an ever increasing population and increased demands for ruminant products, the need to ensure future food security is paramount [1]. This presents a major challenge to find novel strategies to sustainably increase animal productivity. The main challenge for the livestock sector is increasing the conversion of plant to microbial protein within the rumen which is inefficient as only around $30 \%$ of ingested nitrogen is retained by the animal for meat and milk production [2-5]. Thus in pasture-based feeding systems the plant-microbe inter-actome is central for utilisation of plant nutrients [3,5,6]. Furthering our understanding of plant-microbe interactions during colonisation and plant degradation is expected to offer novel opportunities to improve ruminant nutrient use efficiency in order to sustainably increase meat and milk availability.

The ability of the rumen microbiota to attach in a timely manner to ingested forages in the rumen is central to ruminant nutrient use efficiency. Indeed, it is known that rumen microorganisms rapidly attach to recently ingested feed particles [7-13]. We have also demonstrated that not only does bacterial colonisation of fresh whole perennial ryegrass in the rumen occur within 15 minutes, but this is not a stable community with a change in the diversity of attached bacteria from primary to secondary attached communities occurring within 2 $-4 \mathrm{~h}$ of perennial ryegrass colonisation [13]. Rumen microorganisms colonising the surfaces of forages are confronted with highly variable physiochemical conditions including nutrient type and availability due to the heterogeneity of the plant material. This heterogeneity may affect microbial attachment and subsequent biofilm formation. Indeed, plant degradation within the rumen is known to be affected by the amount of cuticle, waxes or lignin and the degree of cross-linkage to other cell- wall polymers within the plant [14,15]. McAllister et al. stated that rumen bacteria do not bind to the waxy cuticle of forage particles due to the difficulty in degrading these structures in order to access the plant nutrients [6]. Thus, bacterial attachment to different parts of the plant material may be different due to the differences in their surface chemistry.

We investigated the hypothesis that attachment of the rumen microbiota to plant material is affected by the physicochemical properties of forage structures. It has been documented that PRG stem and leaves differ chemically $[16,17]$, and wax chemistry on abaxial and adaxial surfaces differ [18], nonetheless colonisation of PRG by the rumen microbiota is often investigated without taking into account that composition of different plant structures vary. These approaches often miss fundamental information on the interactions of key microbiota with various plant structures and the subsequent effect on degradation of various structures within the whole plant. Hence, the first experiment compared bacterial colonization of fresh perennial ryegrass stems and leaves and the second experiment assessed

${ }^{*}$ Corresponding author: Sharon A. Huws, Institute of Biological, Environmental and Rural Sciences (IBERS), Aberystwyth University, Penglais campus, Aberystwyth, SY23 3FG, UK, Tel: +44 1970 823202; Fax: +44 1970823155 ; E-mail: hnh@aber.ac.uk

Received January 20, 2014; Accepted February 03, 2014; Published February 07, 2014

Citation: Huws SA, Mayorga OL, Theodorou MK, Kim EJ, Cookson AH, et al (2014) Differential Colonization of Plant Parts by the Rumen Microbiota is likely to be due to Different Forage Chemistries. J Microb Biochem Technol 6: 080-086. doi:10.4172/1948-5948.1000126

Copyright: ( 2014 Huws SA, et al. This is an open-access article distributed under the terms of the Creative Commons Attribution License, which permits unrestricted use, distribution, and reproduction in any medium, provided the original author and source are credited 
attachment of rumen bacteria to each side of the colonised leaf (abaxial versus adaxial). Knowledge of bacterial colonization of different parts of forage plants aids our understanding of bacterial niche preference. Increasing our knowledge of rumen plant-microbe interactions is paramount in order to develop novel strategies of improving ruminant nutrient use efficiency and ultimately ensure ruminant food security.

\section{Materials and Methods}

\section{Growth and preparation of plant material}

Perennial ryegrass, (Lolium perenne cv. Aberdart; PRG) was grown from seed in plastic seed trays (length $38 \mathrm{~cm} x$ width $24 \mathrm{~cm} x$ depth 5 $\mathrm{cm}$ ) filled with compost (Levingtons general purpose). The trays were maintained in a greenhouse under natural irradiance with additional illumination provided during the winter months (minimum $8 \mathrm{~h}$ photoperiod) or in a growth cabinet (Sanyo, Osaka) with $16 \mathrm{~h}$ of light (irradiance $\sim 300 \mu \mathrm{mol} \mathrm{m}-2 \mathrm{~s}^{-1}$ ) per day. A temperature of $22 / 19^{\circ} \mathrm{C}$ day/ night was maintained and plants were watered twice a week.

\section{In vitro incubations: stem and leaf colonisation}

Following 6 weeks of growth the plant material was cut with scissors at $3 \mathrm{~cm}$ above soil level and divided into stems and leaves. Sub-samples of stems and leaves were frozen, freeze-dried and stored at $-20^{\circ} \mathrm{C}$ for chemical analysis and bacterial profiling $(0 \mathrm{~h}$ samples $)$. Chemical analyses of stem and leaf samples were carried out as described in Huws et al. [19]. Subsequently, cut stem or leaves $(1 \mathrm{~cm}$; $7.5 \mathrm{~g}$ ) were added to Duran bottles $(250 \mathrm{~mL})$ together with anaerobic incubation buffer $\left(135 \mathrm{~mL}\right.$ pre-warmed to $39^{\circ} \mathrm{C}$ [20] and rumen fluid inoculum $(15 \mathrm{~mL}$, strained through 2 layers of muslin and held under $\mathrm{CO}_{2}$ at $39^{\circ} \mathrm{C}$ ). Bottles were incubated in a horizontally rotating rack at $100 \mathrm{rpm}$ and $39^{\circ} \mathrm{C}$ (Incubator-shaker, LA Engineering, UK). Incubations were set up in sextuplicate and the bottle contents were harvested at $0,0.25,0.5,1,2,4,8,12$ and $24 \mathrm{~h}$. At each time interval the contents of three of the bottles contents were harvested individually by vacuum filtration through filter paper $\left(11 \mu \mathrm{m}^{2}\right.$ pore size; 'QL100, Fisher Scientific, Leicestershire, UK). Retained, colonised plant material was washed with phosphate buffered saline (PBS), frozen at $-20^{\circ} \mathrm{C}$, before freeze-drying and grinding followed by DNA extraction. At each time interval the contents of the remaining three bottles were oven dried and plant degradation was measured as $\%$ dry matter lost.

\section{In vitro incubations: adaxial and abaxial colonisation}

Following 6 weeks of growth the plant material was cut with scissors at $3 \mathrm{~cm}$ above soil level and leaves were harvested and cut into $1 \mathrm{~cm}$ strips. The chopped grass was used as substrate for anaerobic batch cultures set up in Duran bottles $(250 \mathrm{~mL})$ using rumen fluid inoculum prepared as described above and incubated for $0,2,4$, and $8 \mathrm{~h}$. Following incubation, a set of six bottles were harvested at the designated times and split into two groups of three bottles. The first group of three bottles was used as positive controls for whole leaf colonisation; the leaf fragments from those bottles were collected by vacuum filtration through filter paper $\left(11 \mu \mathrm{m}^{2}\right.$ pore size; 'QL100, Fisher Scientific, Leicestershire, UK), rinsed in PBS then frozen at $-20^{\circ} \mathrm{C}$ before freeze-drying and grinding followed by DNA extraction. The second group of bottles was used to assess the quantity and diversity of rumen bacteria on each side of the colonised leaf. Essentially, at each time interval, abaxial and adaxial leaf surfaces (from 100 leaf fragments) were placed on 10 microscope slides (10 per slide) and silicone rubber spread across the leaf surfaces with a brush. The silicone rubber (Magnacrafty, Midhurst, UK) was mixed with catalyst (Trylon Ltd, Northants, UK) (7 parts of rubber: 1 part of catalyst) causing it to set in 30 to $60 \mathrm{~min}$. A second microscope slide was placed on top of the set layer and slight pressure carefully applied to the upper slide to facilitate the adherence of epidermal and microbial cells to the rubber film, before leaving overnight at $4^{\circ} \mathrm{C}$. After setting overnight, the silicone rubber and accompanying epidermal cells and bacteria were removed from the unwanted side of the leaf fragments using forceps. The modified leaf blades were then washed with PBS, frozen at $-20^{\circ} \mathrm{C}$ and then freeze dried and ground. This method enabled selective removal of the adaxial or abaxial surface, and thus quantification of the colonisation on the surface left behind on the leaf fragment. Effective removal was assessed by staining the latex film after removal from plant fragments using the fluorescent dye DiOC6 (3)-(3,3'-dihexyloxacarbocyanine iodide) (Sigma-Aldrich Company, Ltd., Dorset, UK) [21]. Removal of bacteria from leaf surfaces was also visually confirmed by low temperature scanning electron microscopy of stripped unwanted surfaces as described by Huws et al. [13] (data not shown).

\section{DNA extraction and denaturing gradient gel electrophoresis}

DNA extraction, PCR-DGGE and subsequent gel fingerprinting, using the primers 799FGC(5'CGCCCGCCGCGCGCGGCGGGCGG GGCGGGGGCACGGGGGGAACAGGATTAGATACCCTG3') and R1401 (5'CGGTGTGTACAAGACCC3') was performed as described by Edwards et al. and Huws et al. [12,13]. Resultant DGGE gels were scanned using a GS-710 calibrated imaging densitometer (Bio-Rad UK Ltd, Hemel Hempstead, UK) and the saved image imported into the software package Fingerprinting (Bio-Rad UK Ltd, Hemel Hempstead, UK) for analysis. Cluster analysis was performed using Dice, with a position tolerance of $0.5 \%$ and optimisation parameter of $0.5 \%$. The binary data generated from DGGE based fingerprinting was used to conduct canonical analysis of principal coordinates (CAP).

\section{S rDNA quantitative PCR}

Total bacterial $16 \mathrm{~S}$ rDNA quantitation using QPCR was performed as described by Huws et al. using the primers 520F (5'AGCAGCCGCGGTAAT3') and 799R2 (5'CAGGGTATCTAATCCTGTT3') [13]. The quantification was performed using a 7500 real-time PCR system (Applied Biosystems, Warrington, UK) using the same standards as described in Huws et al. [13]. Results were analysed using the 7500 SYSTEM SDS software (Applied Biosystems, Warrington, UK). QPCRs were performed in triplicate and assay PCR efficiency was calculated as follows: efficiency $=10(-1 /$ slope $) \times 100$. QPCR efficiency was always between $90-110 \%$, and correlations of genomic DNA standards were $>0.97$.

\section{Determination of biofilm coverage on abaxial and adaxial surfaces}

To estimate the extent of coverage of biofilm communities on abaxial and adaxial leaf surfaces, four leaves (to allow examination of two adaxial and two abaxial surfaces) for each of three replicates at each incubation time were analysed by LTSEM as described by Huws et al. [13]. The LTSEM analysis was carried out by random scanning of surfaces at x 2200 magnification and a resolution of $10 \mu \mathrm{m}$ at $3.0 \mathrm{kV}$. In total, 40 frames were analysed per surface and these were recorded as digital images using SEMAPHORE software. In total 120 digital images were processed using the digital image analysis software, NIH Image (Windows version available from Scion Corporation, U.S.A (http:// www.scioncorp.com). The digital images were converted to threshold images, and particle size analysis was subsequently carried out to count 
Citation: Huws SA, Mayorga OL, Theodorou MK, Kim EJ, Cookson AH, et al. (2014) Differential Colonization of Plant Parts by the Rumen Microbiota is likely to be due to Different Forage Chemistries. J Microb Biochem Technol 6: 080-086. doi:10.4172/1948-5948.1000126

and measure the biofilm coverage. The area of particles was computed, and size and coverage of biofilms quantified in pixels. The analysis was carried out on particle sizes ranging from 1 to 999999 square pixels. The area covered by biofilms in the randomly selected frames was measured as the percentage of pixels detected relative to the area of the measurement frame (total area of 2015544 square pixels per frame).

\section{Statistical analysis}

For IVDMD, QPCR and biofilm coverage data, two-way analysis of variance (ANOVA) was conducted and differences among means were determined by Duncan's multiple range tests [22] using Gen Stat (Tenth Edition, VSN International Ltd., Hemel Hemstead, UK) [23]. For plant composition data, one-way analysis of variance (ANOVA) was conducted and differences among means were determined by Duncan's multiple range tests [22] using Gen Stat. Primer 6 and PERMANOVA+ (version 6; Primer-E, Ivy bridge, UK) respectively were used to conduct canonical analysis of principal coordinates (CAP) [24] and permutation multivariate analysis of variance (PERMANOVA) [25] on DGGE generated binary data.

\section{Results}

\section{Plant dry matter (DM) and chemical composition}

DM did not vary significantly between stem and leaf material $(\mathrm{P}>0.05)$ (Table 1). Nonetheless, chemical compositional differences were found between stem and leaf in terms total nitrogen, water soluble carbohydrate (WSC) neutral-detergent fibre (NDF), acid-detergent lignin (ADL), and alkanes/lipid content (Table 1). Specifically, the stem contained significantly $(\mathrm{P}<0.001)$ more WSC, NDF and ADL but significantly less total nitrogen than the leaf.

\section{In vitro dry matter degradation}

IVDMD was significantly different $(\mathrm{P}<0.001)$ between leaf and stem incubations (Table 2). Leaf material was degraded to a greater extent than stem material with 69.2 and $58.9 \%$ being degraded for leaf and stem material respectively after $24 \mathrm{~h}$ incubation (Table 2). Degradation of leaf was also far more rapid than stem material with 32.2 and $9.1 \%$ being degraded for leaf and stem material respectively after $2 \mathrm{~h}$ of incubation (Table 2 ).

\section{Attached bacterial diversity}

PCR-DGGE derived UPGMA dendrograms revealed that the microbiota attached to either stem or leaf were markedly different at each incubation time (Figure 1A; maximum similarity 40\%). As sample number exceeded gel capacity and comparisons between different DGGE gels are challenging, multiple gels were run in order to analyse all samples. Figure 1A shows a representative DGGE gel for one replicate of the three taken. Some sub-clustering of attached bacteria was also evident for stem and leaf attached microbiota between 2 and $4 \mathrm{~h}$ of colonisation (Figure 1A; maximum similarity was 40 and 55\% between 2 and $4 \mathrm{~h}$ leaf and stem attached microbiota respectively). Canonical analysis of principal coordinates (CAP) ordination confirmed data for the PCR-DGGE derived UPGMA dendrograms (Figure 1B) by illustrating that the complexity of microbiota adhering to stem and leaves differed at each time point, but the 2 to $4 \mathrm{~h}$ differences are not so clear from these graphs. PERMANOVA supported the graphical data and showed that in the presence of stem or leaf material the attached microbiota differed significantly from each other $(P>0.001$, Pseudo-F=4.00).

PCR-DGGE derived UPGMA dendrograms revealed that the microbiota attached to either abaxial or adaxial leaf surface did not differ markedly at any of the time intervals (Figure 2A). Canonical analysis of principal coordinates (CAP) ordination confirmed data for the PCR-DGGE derived UPGMA dendrograms (Figure 2B) by showing similarity in the bacterial $16 \mathrm{SrDNA}$ diversity colonising the abaxial and adaxial leaf surface. Regardless of leaf surface there was discrimination between populations according to the duration of incubation (Figure 2B). PERMANOVA also confirmed that bacteria colonising abaxial and adaxial leaf surfaces did not differ significantly $(\mathrm{P}=0.75$, Pseudo- $\mathrm{F}=0.68)$.

\section{Attached bacterial quantity}

The microbiota attached to stem and leaf were not different from each other in terms of $16 \mathrm{~S}$ rDNA quantities (Table 3). Nonetheless, time had a significant effect on quantities of $16 \mathrm{~S}$ rDNA determined on both stem and leaf, with 3.0 and $3.1 \times$ times as much attached bacterial $16 \mathrm{~S}$ rDNA present following $24 \mathrm{~h}$ of incubation on leaf and stem material respectively, compared to initial $16 \mathrm{~S}$ rDNA quantities (Table 3).

\begin{tabular}{|c|c|c|c|}
\hline Constituent g $100 \mathrm{~g}^{-1} \mathrm{DM}$ & Leaf & Stem & $\mathbf{P}$ \\
\hline Dry matter [DM] & $18.4( \pm 0.03)$ & $19.1( \pm 0.94)$ & NS \\
\hline Total nitrogen [total-N] & $3.0( \pm 0.03)$ & $1.4( \pm 0.04)$ & $<0.001$ \\
\hline Water-soluble carbohydrates [WSC] & $14.2( \pm 0.11)$ & $26.9( \pm 1.04)$ & $<0.001$ \\
\hline Neutral- detergent fibre [NDF] & $37.2( \pm 0.27)$ & $42.8( \pm 0.28)$ & $<0.001$ \\
\hline Acid-detergent fibre [ADF] & $20.0( \pm 0.60)$ & $20.9( \pm 0.11)$ & NS \\
\hline Acid-detergent lignin [ADL] & $3.9( \pm 0.10)$ & $5.1( \pm 0.2)$ & $<0.001$ \\
\hline Alkanes/Lipid & $3.9( \pm 0.06)$ & $1.5( \pm 0.06)$ & $<0.001$ \\
\hline
\end{tabular}

NS: not significant. $n=3( \pm$ SEM). DM: dry matter

Table 1: Dry matter and chemical composition of leaf and stem fragments isolated from perennial ryegrass harvested after 6 weeks growth from seed.

\begin{tabular}{|c|c|c|c|c|c|c|c|c|c|c|c|c|}
\hline & \multicolumn{8}{|c|}{ Incubation times (h) } & \multirow{2}{*}{$\begin{array}{c}\text { SED } \\
\mathbf{T}\end{array}$} & \multirow[b]{2}{*}{$\mathbf{F}$} & \multirow{2}{*}{$\begin{array}{l}\mathbf{P} \\
\mathbf{T}\end{array}$} & \multirow{2}{*}{$\mathbf{F}$} \\
\hline & 0 & 0.25 & 0.5 & 1 & 2 & 4 & 8 & 24 & & & & \\
\hline Leaf & $0.0 a$ & $14.1 \mathrm{~b}$ & $23.1 \mathrm{c}$ & $28.8 \mathrm{~cd}$ & 32.8de & $36.2 \mathrm{e}$ & $44.0 f$ & $69.2 \mathrm{~g}$ & 0.79 & 1.59 & $<0.001$ & $<0.001$ \\
\hline Stem & $0.0 a$ & $1.8 a$ & $5.3 b$ & $9.1 \mathrm{c}$ & $12.2 \mathrm{~cd}$ & $15.2 d$ & $29.0 \mathrm{e}$ & $58.9 f$ & & & & \\
\hline
\end{tabular}

$\mathrm{T}$, effect of incubation time.F, effect of plant fragment. Duncan's tests were performed between row means but not between column means; $\mathrm{F} x \mathrm{~T}$ interaction effects were not significant. Values within the same row with different superscripts were significantly different $(P<0.05)$. NS: not significant

Table 2: In vitro dry matter degradation (IVDMD) of leaf and stem fragments of perennial ryegrass incubated for up to $24 \mathrm{~h}$ with mixed rumen bacteria. Data is expressed as $\mathrm{g}$ DM lost from $100 \mathrm{~g}$ initial DM. 
Citation: Huws SA, Mayorga OL, Theodorou MK, Kim EJ, Cookson AH, et al. (2014) Differential Colonization of Plant Parts by the Rumen Microbiota is likely to be due to Different Forage Chemistries. J Microb Biochem Technol 6: 080-086. doi:10.4172/1948-5948.1000126

\section{용요 용ㅇำ}
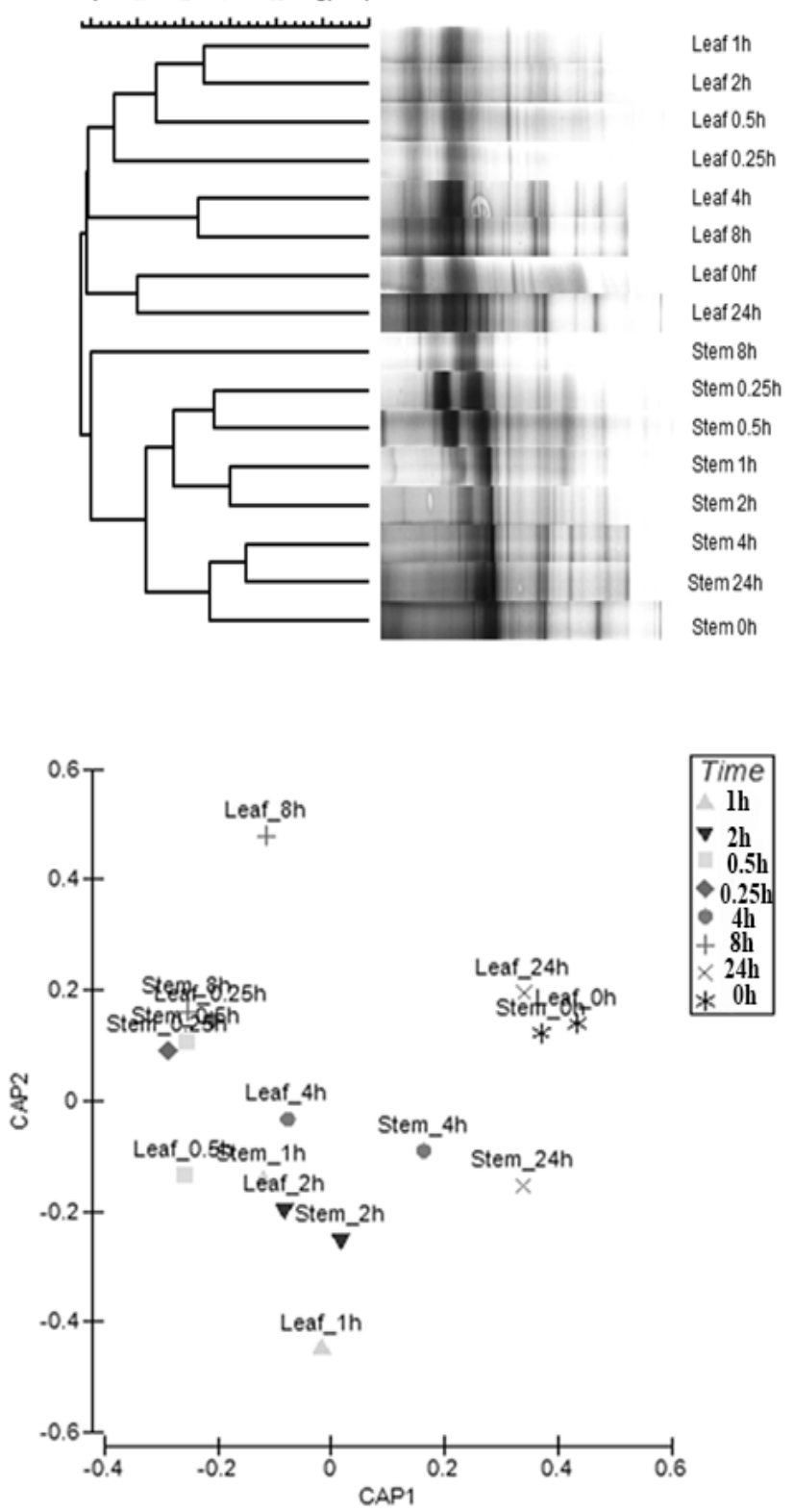

Figure 1: 16S rDNA DGGE-based unweighted pair group method with arithmetic mean (UPGMA) dendrogram showing diversity of fresh perennial ryegrass stem and leaf attached rumen bacteria $(A)$ and corresponding canonical analysis of principal coordinates (CAP) ordination (B). Scale on the UPGMA dendrogram relates to \% similarity.

Conversely, abaxial and adaxial attached microbiotas were significantly different from each other in terms of $16 \mathrm{~S}$ rDNA quantities (Table 4). After $8 \mathrm{~h}$ of incubation bacterial $16 \mathrm{~S}$ rDNA quantity was greatest on the adaxial surface compared with the abaxial surface with 2.2 and $3.2 \mathrm{ng} \mathrm{g}^{-1} \mathrm{RDM}$ bacterial $16 \mathrm{~S}$ rDNA present on the abaxial and adaxial leaf surfaces respectively (Table 4 ). When added together abaxial and adaxial 16S rDNA quantities were equal to, or at least very close, to the data obtained for whole leaves, thus showing that the stripping methodology was very effective (Table 4). Fluorescent dye DiOC6 (3)-(3,3'-dihexyloxacarbocyanine iodide) staining of leaf surfaces post stripping as well as LTSEM also confirmed the absence of bacteria on stripped surfaces (data not shown). No effect of time was identified in terms of $16 \mathrm{~S}$ rDNA abundance regardless of leaf surface.

\section{Biofilm coverage}

Biofilm coverage data was in agreement with $16 \mathrm{~S}$ rDNA QPCR data in showing that adaxial surfaces had a greater coverage of attached bacteria than abaxial surfaces (Table 5). Following $1 \mathrm{~h}$ of incubation the abaxial surface had $40.6 \%$ coverage whilst the adaxial surface had $74.2 \%$ coverage (Table 5). By $8 \mathrm{~h}$ the differential had decreased with the abaxial surface having $65.9 \%$ coverage and the adaxial surface $77.1 \%$ (Table 5). 0h data showed very little colonisation by plant epiphytic communities (data not shown).

\section{Discussion}

Increasing the efficiency of feed degradation is a key target for

A.
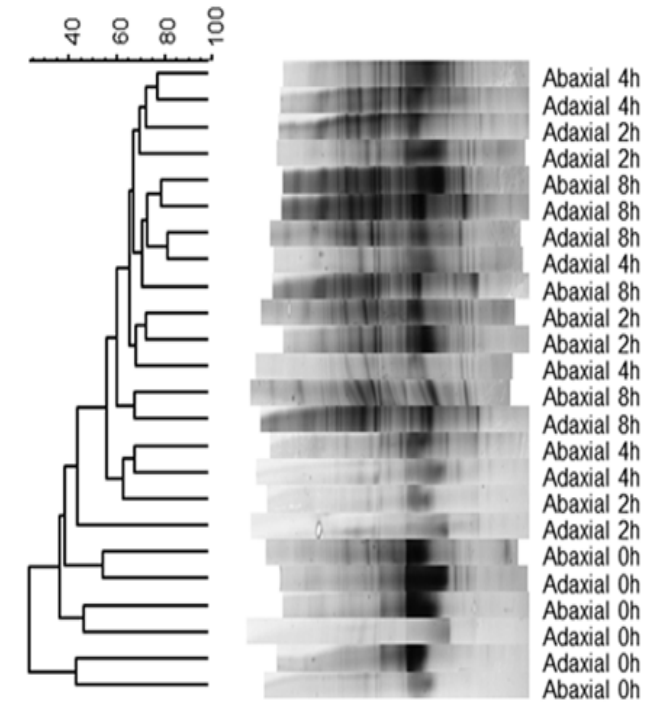

B.

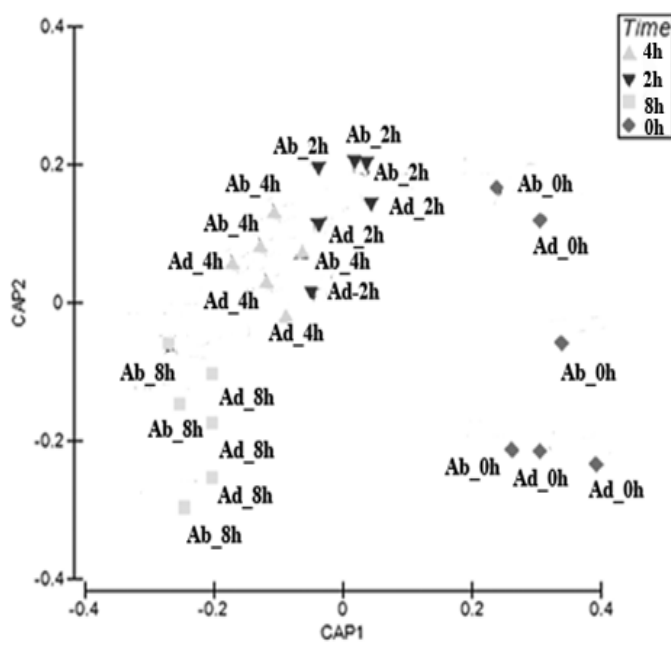

Figure 2: 16S rDNA DGGE-based unweighted pair group method with arithmetic mean (UPGMA) dendrogram showing diversity of rumen bacteria attached to abaxial and adaxial surfaces of fresh perennial ryegrass leaves (A) and corresponding canonical analysis of principal coordinates (CAP) ordination (B). Scale on the UPGMA dendrogram relates to \% similarity. 
Citation: Huws SA, Mayorga OL, Theodorou MK, Kim EJ, Cookson AH, et al. (2014) Differential Colonization of Plant Parts by the Rumen Microbiota is likely to be due to Different Forage Chemistries. J Microb Biochem Technol 6: 080-086. doi:10.4172/1948-5948.1000126

\begin{tabular}{|c|c|c|c|c|c|c|c|c|c|c|c|c|}
\hline \multirow{2}{*}{ Plant fragment } & \multicolumn{8}{|c|}{ Incubation times (h) } & \multirow{2}{*}{$\begin{array}{c}\text { SED } \\
\mathbf{T}\end{array}$} & \multirow[b]{2}{*}{$\mathbf{F}$} & \multirow{2}{*}{$\mathbf{T}$} & \multirow[b]{2}{*}{$\mathbf{F}$} \\
\hline & 0 & 0.25 & 0.5 & 1 & 2 & 4 & 8 & 24 & & & & \\
\hline Leaf & $1.5 a$ & $1.8 a b$ & $2.3 c$ & $2.3 c$ & $2.5 d$ & $3.2 \mathrm{e}$ & $4.4 \mathrm{f}$ & $4.6 \mathrm{~g}$ & 0.14 & 0.07 & $<0.001$ & NS \\
\hline Stem & $1.6 a$ & $1.7 \mathrm{a}$ & $1.9 \mathrm{bc}$ & $2.0 c$ & $2.4 d$ & $3.0 \mathrm{e}$ & $4.2 f$ & $5.0 \mathrm{~g}$ & & & & \\
\hline
\end{tabular}

$\mathrm{T}$, effect of incubation time. $\mathrm{F}$, effect of plant fragment $\mathrm{F} \times \mathrm{T}$ interaction effects was not significant. Values within the same row with different superscripts were significantly different $(P<0.05)$. SED, standard errors of differences of means

Table 3: Bacterial 16S rDNA quantity (ng g ${ }^{-1}$ Remaining Dry Matter (RDM)) attached to leaf and stem fragments incubated for up to $24 \mathrm{~h}$ in the presence of mixed rumen bacteria.

\begin{tabular}{|c|c|c|c|c|c|c|c|}
\hline \multirow{2}{*}{ Leaf surface } & \multicolumn{4}{|c|}{ Incubation times (h) } & \multicolumn{2}{|c|}{ SED } \\
\cline { 2 - 7 } & $\mathbf{0}$ & $\mathbf{2}$ & $\mathbf{4}$ & $\mathbf{8}$ & Time & Surface & Time \\
\hline Whole leaf & $1.9 \mathrm{a}$ & $3.7 \mathrm{~b}$ & $3.8 \mathrm{~b}$ & $5.2 \mathrm{c}$ & 0.13 & 0.11 \\
\hline Abaxial & $1.0 \mathrm{a}$ & $1.8 \mathrm{~b}$ & $1.9 \mathrm{~b}$ & $2.2 \mathrm{c}$ & & $<0.001$ \\
\hline Adaxial & $1.1 \mathrm{a}$ & $2.0 \mathrm{~b}$ & $2.4 \mathrm{~b}$ & $3.2 \mathrm{c}$ & & \\
\hline
\end{tabular}

$\mathrm{T}$, effect of incubation time.F, effect of plant fragment. $\mathrm{F} \times \mathrm{T}$ interaction effects was not significant. Values within the same row with different superscripts were significantly different $(P<0.05)$. SED, standard errors of differences of means.RDM, remaining dry matter

Table 4: Bacterial 16S rDNA quantity (ng g ${ }^{-1}$ Remaining Dry Matter (RDM)) attached to abaxial and adaxial leaf surfaces following incubation of leaves for up to $24 \mathrm{~h}$ in the presence of mixed rumen bacteria.

\begin{tabular}{|c|c|c|c|c|c|c|c|c|}
\hline \multirow{2}{*}{$\begin{array}{c}\text { Leaf } \\
\text { Surface }\end{array}$} & \multicolumn{4}{|c|}{ Incubation times (h) } & \multirow{2}{*}{$\begin{array}{c}\text { SED } \\
T\end{array}$} & \multirow[b]{2}{*}{$\mathbf{S}$} & \multirow{2}{*}{$\begin{array}{l}\mathbf{P} \\
\mathbf{T}\end{array}$} & \multirow[b]{2}{*}{$\mathbf{S}$} \\
\hline & 1 & 2 & 4 & 8 & & & & \\
\hline Abaxial & 40.6 & 49.7 & 52.8 & 65.9 & 3.61 & 2.55 & $<0.01$ & $<0.001$ \\
\hline Adaxial & 74.2 & 78.4 & 80.1 & 77.1 & & & & \\
\hline
\end{tabular}

T, effect of incubation time; S, effect of leaf surface. SED, standard error of the difference of the means, where $n=10$ (no. of frames per time point)

Table 5: Percentage biofilm coverage on perennial ryegrass adaxial and abaxial leaf surfaces following incubation under in vitro rumen-like conditions.

ruminant bioscience. Central to this target is efficient fermentation of forage, which requires rapid and effective colonisation of newly ingested feed by rumen bacteria to drive fibre degradation. In this study we investigated the hypothesis that attachment of the rumen microbiota to plant material is affected by the physicochemical properties of forage structures. Within this study we demonstrate that differing plant parts can have a profound effect on attached bacterial diversity and/ or $16 \mathrm{~S}$ rDNA quantity. Colonisation of forages by rumen microbiota is commonly investigated without consideration of the effects of different plant structures on attachment of the microbiota, and likewise chemical composition of perennial ryegrass is often assessed using the whole plant. These approaches often miss fundamental information on the interactions of key microbiota with various plant structures and the subsequent effect on degradation of various structures within the whole plant. The heterogeneity of forage degradation has previously been shown in Lotus, where tannin containing cells were under graded by the rumen microbiota [26]. This study aids our understanding of niche specialisation of the attached rumen microbiota related to plant chemistry and thereby contributes towards developing novel strategies of improving ruminant nutrient use efficiency to ensure food security.

Stem material had more fibre and lignin content than leaves, which means that this part of the plant is potentially more difficult for the rumen microbiota to digest. Chemical composition data for stem and leaves in this study are similar to those reported previously $[27,28]$. This differential in recalcitrant cell wall structure between stem and leaves is the most likely explanation for the reduced IVDMD of stem material compared to leaves. Indeed, Chaves et al. also reported that DM degradability for leaf is higher than for stem material for perennial ryegrass, tall fescue, Yorkshire fog, Phalaris and Paspalum grass species [27].

PCR-DGGE derived UPGMA dendrograms, CAP analysis and PERMANOVA revealed that microbiota attached to the stem and leaf was markedly different from each other at all incubation times.
QPCR data showed that although diversity of the attached bacteria was different, bacterial 16S rDNA quantity did not differ in the presence of stem or leaf material. Shinkai et al. also noted using fluorescence in situ hybridization (FISH) and QPCR, that more Fibrobacter succinogenes and Ruminococcus flavefaciens associated with leaves compared to stems of orchard grass hay [29]. Also noteworthy is the fact that shifts in attached bacterial diversity occurred between 2 and $4 \mathrm{~h}$ incubation on both stem and leaf material. Indeed, we previously noted this change from primary to secondary colonisation between these time intervals [13]. We therefore predict that this differential preference in colonization behaviour could underlie observed differences in degradation of leaf and stem material if it is associated with differential functionalities. This would require more detailed investigation such as RNA seq to confirm this hypothesis.

Bacterial communities of abaxial and adaxial leaf surfaces were similar, but QPCR and quantitative LTSEM data showed that more bacteria colonised the adaxial surface compared to the abaxial surface. There are currently few reports regarding differential bacterial diversity on the adaxial and abaxial surfaces of fresh perennial ryegrass. Akin found different morphological types of rumen bacteria on different plant surfaces by electronic microscopy [30]. Results from studies with mixed bacterial cultures have also shown differences in the attachment of rumen bacteria to plant cell types e.g. Bacteroides but not Ruminococcus adhered to intact mesophyll cell wall [31]. It has been suggested that distinct rumen bacterial species probably colonise plant surfaces in different ways, due to their distinct growth and survival requirements [32]. This differential in microbiota attached to abaxial and adaxial surfaces of perennial ryegrass may be due to differential chemo-attraction and physical barrier effects described in early studies [33-35] or differential electrostatic interactions that could be present on different sides of the leaf [36]. Adaxial surfaces have been reported to have more waxes containing long-chain alkanes, alcohols, ketones, and fatty acids as compared to the abaxial surface $[36,37]$. Therefore, the hydrophobicity of the cell surface may be important 
Citation: Huws SA, Mayorga OL, Theodorou MK, Kim EJ, Cookson AH, et al. (2014) Differential Colonization of Plant Parts by the Rumen Microbiota is likely to be due to Different Forage Chemistries. J Microb Biochem Technol 6: 080-086. doi:10.4172/1948-5948.1000126

in adhesion as hydrophobic interactions tend to increase with the increasing non-polar nature of one or both surfaces involved i.e., the microbial cell surface and the substratum surface $[8,38,39]$. Most bacteria are negatively charged but still contain hydrophobic surface components [40,41], for instance, F. succinogenes cells adhere better to cationic cellulose ethers than neutral crystalline cellulose, whereas anionic cellulose-ethers reduced adhesion of this bacterium $[8,42]$. The adaxial surface has also been reported to have more stomata present, which have been reported as easy bacterial plant entry structures for subsequent plant degradation [7,43]. Irrespective, it appears that rumen bacteria colonise perennial ryegrass adaxial surfaces to a greater extent than colonisation of abaxial surfaces.

In summary we demonstrate that differing plant structures can have a profound effect on attached bacterial diversity and/or $16 \mathrm{~S}$ rDNA quantity likely due to their differing chemistry. This suggests that the rumen microbiota display niche specialisation in terms of plant degradation. This data illustrates the importance of investigating intra-plant colonisation to get a deeper fundamental understanding of the plant-microbe interactome. Furthering our understanding of the ruminal plant-microbe interactome, in particular how the plant cell can be optimised through plant breeding to deliver nutrients in a manner suitable to maximise microbial efficiency [5], is fundamental to the development of novel strategies to increase ruminant production in order to meet increasing demand for meat and milk.

\section{Acknowledgements}

We acknowledge funding from COLCIENCIAS, CORPOICA (Colombia) and the Biotechnology and Biological Sciences Research Council (BBSRC, UK). We are also grateful to Mark Scott for his technical assistance in setting up the experiments. The authors have no conflict of interest.

\section{References}

1. FAOSTAT (2009)

2. MacRae JC, Ulyatt MJ (1974) Quantitative digestion of fresh herbage by sheep. 2. Sites of some nitrogenous constituents. J AgricSci 82: 309-319.

3. Dewhurst RJ, Mitton AM, Offer NW, Thomas C. (1996) Effect of the composition of grass silages on milk production and nitrogen utilisation by dairy cows. Animal Sci 62: 25-34.

4. Kingston-Smith AH, Davies TE, Edwards JE, Theodorou MK (2008) From plants to animals; the role of plant cell death in ruminant herbivores. J Exp Bot 59: 521-532.

5. Kingston-Smith AH, Edwards JE, Huws SA, Kim EJ, Abberton M (2010) Plantbased strategies towards minimising 'livestock's long shadow'. ProcNutrSoc 69: 613-620.

6. McAllister TA, Bae HD, Jones GA, Cheng KJ (1994) Microbial attachment and feed digestion in the rumen. J AnimSci 72: 3004-3018.

7. Cheng KJ, Fay JP, Howarth RE, Costerton JW (1980) Sequence of events in the digestion of fresh legume leaves by rumen bacteria. Appl Environ Microbio 40: 613-625.

8. Miron J, Ben-Ghedalia D, Morrison M (2001) Invited review: adhesion mechanisms of rumen cellulolytic bacteria. J Dairy Sci 84: 1294-1309.

9. Russell JB, Rychlik JL (2001) Factors that alter rumen microbial ecology. Science 292: 1119-1122.

10. Koike S, Pan J, Kobayashi Y, Tanaka K (2003) Kinetics of in sacco fiberattachment of representative ruminal cellulolytic bacteria monitored by competitive PCR. J Dairy Sci 86: 1429-1435.

11. Edwards JE, Huws SA, Kim EJ, Kingston-Smith AH (2007) Characterization of the dynamics of initial bacterial colonization of nonconserved forage in the bovine rumen. FEMS MicrobiolEcol 62: 323-335.

12. Edwards JE, Kingston-Smith $A H$, Jimenez HR, Huws SA, Skøt KP, et al. (2008) Dynamics of initial colonization of nonconserved perennial ryegrass by anaerobic fungi in the bovine rumen. FEMS MicrobiolEcol 66: 537-545.
13. Huws SA, Mayorga OL, Theodorou MK, Onime LA, Kim EJ, et al. (2013) Successional colonization of perennial ryegrass by rumen bacteria. LettAppIMicrobiol 56: 186-196.

14. Jung HG, Allen MS (1995) Characteristics of plant cell walls affecting intake and digestibility of forages by ruminants. J AnimSci 73: 2774-2790.

15. Wilson JR, Mertens DR (1995) Cell wall accessibility and cell structure limitations to microbial digestion of forage. Crop Sci 35: 251-259.

16. Gordon AH, Lomax JA, Dalgarno K, Chesson A (1985) Preparation and composition of mesophyll, epidermis and fiber cell walls from leaves of parenial ryegrass (Loliumperenne) and italian ryegrass (Loliummultiflorum). J Sci Food Agric 36: 509-519.

17. Akin DE, Borneman WS, Lyon CE (1990) Degradation of leaf blades and stems by monocentric and polycentric isolates of ruminal fungi. An Feed SciTechno 31: 202-221.

18. Ringelmann A, Riedel M, Riederer M, Hildebrandt U (2009) Two sides of a leaf blade: Blumeriagraminis needs chemical cues in cuticular waxes of Loliumperenne for germination and differentiation. Planta 230: 95-105.

19. Huws SA, Lee MR, Kingston-Smith AH, Kim EJ, Scott MB, et al. (2012) Ruminalprotozoal contribution to the duodenal flow of fatty acids following feeding of steers on forages differing in chloroplast content. $\mathrm{Br} J$ Nutr 108 2207-2214.

20. Van Soest PJ (1967) Development of a comprehensive system of feed analyses and its application to forages. J AnimSci 26: 119-128.

21. Terasaki M (1989) Fluorescent labeling of endoplasmic reticulum. Methods Cell Biol 29: 125-135.

22. Duncan BB (1955) Multiple range and multiple F-test. Biometrics 11: 1-42.

23. Payne RW, Murray DA, Harding SA, Baird DB, Soutar DM (2007) GenStat ${ }^{\circledR}$ for Windows $^{\text {TM }}$ 9th Edition, Introduction. Hemel Hempstead, UK: VSN International

24. Anderson MJ, Willis TJ (2003) Canonical analysis of principle coordinates: a useful method of constrained ordination for ecology. Ecology 84: 511-525.

25. Anderson MJ (2001) A new method for non-parametric multivariate analysis of variance. Austral Ecol 26: 32-46.

26. Edwards JE, Morris P, Robbins M, Kim EJ, Kingston-Smith AH (2009) Bacterial Colonisation of the tanniferous forage Lotus corniculatus in bovine Rumen. MicrobEcol 57: 569-570.

27. Chaves AV, Burke JL, Waghorn GC, Brookes IM (2006) Digestion kinetics of leaf, stem and inflorescence from five species of mature grasses. J Sci Food Agri 86: 816-825.

28. Sun YZ, Mao SY, Yao W, Zhu WY (2008) DGGE and 16S rDNA analysis reveals a highly diverse and rapidly colonising bacterial community on different substrates in the rumen of goats. Animal 2: 391-398.

29. Shinkai T, Kobayashi Y (2007) Localization of ruminal cellulolytic bacteria on plant fibrous materials as determined by fluorescence in situ hybridization and real-time PCR. Appl Environ Microbiol 73: 1646-1652.

30. Akin DE (1980) Evaluation by electron microscopy and anaerobic culture of types of rumen bacteria associated with digestion of forage cell walls. Appl Environ Microbiol 39: 242-252.

31. Latham MJ, Brooker BE, Pettipher GL, Harris PJ (1978) Adhesion of Bacteroidessuccinogenes in pure culture and in the presence of Ruminococcusflavefaciens to cell walls in leaves of perennial ryegrass (Loliumperenne). Appl Environ Microbiol 35: 1166-1173.

32. Stewart CS, Flint HJ, Byrant MP (1997) The rumen bacteria. IN Hobson, P. N.andStewart, C. S. (Eds.) The Rumen Microbial Ecosystem. 2nd ed. New York, Chapman and Hall: 10-72.

33. Cheng KJ, Akin DE, Costerton JW (1977) Rumen bacteria: interaction with particulate dietary components and response to dietary variation. Fed Proc 36 193-197.

34. Cheng KJ, Fay JP, Coleman RN, Milligan LP, Costerton JW (1981) Formation of bacterial microcolonies on feed particles in the rumen. Appl Environ Microbiol 41: 298-305.

35. Cheng KJ, McAllister TA, Costerton JW (1995) Biofilm of the ruminant digestive tract. In Lappin-Scott H, Costerton JM (Eds.) Microbial Biofilms. Cambridge U.K., Cambridge University Press: 221-232. 
Citation: Huws SA, Mayorga OL, Theodorou MK, Kim EJ, Cookson AH, et al. (2014) Differential Colonization of Plant Parts by the Rumen Microbiota is likely to be due to Different Forage Chemistries. J Microb Biochem Technol 6: 080-086. doi:10.4172/1948-5948.1000126

36. Gniwotta F, Vogg G, Gartmann V, Carver TL, Riederer M, et al. (2005) What do microbes encounter at the plant surface? Chemical composition of pea leaf cuticular waxes. Plant Physiol 139: 519-530.

37. Driscoll SP, Prins A, Olmos E, Kunert KJ, Foyer CH (2006) Specification of adaxial and abaxial stomata, epidermal structure and photosynthesis to $\mathrm{CO} 2$ enrichment in maize leaves. J Exp Bot 57: 381-390.

38. Grabber JH (2005) How do lignin composition, structure, and cross-linking affect degradability? A review of cell wall model studies. Crop Sci 45: 820-831.

39. Eberl L, Von Bodman SB, Fuqua C (2007) Biofilms on plant surfaces. In Kjelleberg S, Givskov M (Eds.) The biofilm mode of life: Mechanisms and adaptations. Sydney, Australia and Lyngby, Denmar, Horizon Bioscience: 215234
40. Costerton JW, Cheng KJ, Geesey GG, Ladd TI, Nickel JC, et al. (1987) Bacterial biofilms in nature and disease. Annu Rev Microbiol 41: 435-464.

41. Pell AN, Schofield $P$ (1993) Microbial adhesion and degradation of plant cell walls Pages IN Hatfield RD, Jung HG, Ralph J, Buxton D R, Mertens DR, Weimer PJ (Eds.) Forage Cell Wall Structure and Digestibility. Madison, WI., USA, ASA-CSSA-SSSA: 397-423.

42. Weimer PJ, Price NP, Kroukamp O, Joubert LM, Wolfaardt GM, et al. (2006) Studies of the extracellular glycocalyx of the anaerobic cellulolytic bacterium Ruminococcusalbus 7. Appl Environ Microbiol 72: 7559-7566.

43. Sant $F$ (1969) A comparison of the morphology and anatomy of seedling leaves of Loliummultiflorum Lam. and L. perenne L. Ann Bot 33: 303-313. 